\title{
Designing Game-Based Learning Kit with Integration of Augmented Reality for Learning Geography
}

\author{
https://doi.org/10.3991/ijim.v16i02.27377 \\ Ong Ace Hong ${ }^{1(凶)}$, Noor Dayana Abd Halim², Nurul Nadwa Zulkifli ${ }^{3}$, \\ Nurul Farhana Jumaat ${ }^{2}$, Norasykin Mohd Zaid², Mahani Mokhtar ${ }^{2}$ \\ 'SMK Dato' Usman Awang, Johor, Malaysia \\ ${ }^{2}$ Faculty of Social Sciences and Humanities, Universiti Teknologi Malaysia, Johor, Malaysia \\ ${ }^{3}$ Faculty of Humanities, Management and Science, Universiti Putra Malaysia \\ (Kampus Bintulu), Sarawak, Malaysia \\ ongacehong@gmail.com
}

\begin{abstract}
The development of education is changing in line with the development of current technology, and these developments have influenced many innovations in teaching and learning methods. Many technology-based games have been introduced in the market; however, not all games are suitable for student learning. This is because the features of a game must have an impact on education; it is essential to choose a game based on appropriate criteria for education. Therefore, this paper describes the integration process of game-based learning features outlined by Alaswad and Nadolny (2015), which are goal, interaction and feedback. The three features are designed in a learning kit called the "Kit Pengembara" for learning the topic of "Wind Direction" and "Bearing Angels", the subject of Geography Form 1. In addition, this Kit Pengembara also integrates the UniteAR application for user to complete a given task using augmented reality. Therefore, this paper can provide an overview to educators in the form of their educational innovations that integrate technology to increase student engagement.
\end{abstract}

Keywords—game-based learning, augmented reality, geography

\section{$1 \quad$ Introduction}

The use of information and communication technology (ICT) in education has rapidly grown around the world, including in Malaysia. ICT in education is not a new concept; it has been implemented in the field for a long time. According to [1], the development of education today has changed in tandem with technology development. Thus, the world of educational technology has now integrated various technologies in education, such as websites, online applications, virtual reality and augmented reality. This is because learning methods will become more interesting with the advent of technology like this. According to [2], augmented reality technology increases learning effectiveness and learning interest among students with real-world scenarios. Cai et al. 
[3] stated that augmented reality technology could easily help students understand abstract concepts and improve students' learning and cognitive abilities. The study conducted by [4] proved that the students' learning performance levels increased after students learnt using augmented reality in learning Science subject. Thus, it can be said that this kind of technology provides many benefits to students as well as helping and facilitating teachers in delivering learning content.

In addition, the selection of the appropriate type of technology and approach when applying technology during teaching and learning sessions is critical to ensure that the technology can be a medium to deliver learning content. One of the appropriate approaches to use is game-based learning. Game-based learning is an integrated process guided by continuous progress driven by optimal challenge and cognitive engagement of students [5]. Past studies have stated that game-based learning produces many positive effects on student learning, such as motivation, achievement and students' perceptions of learning [6]. Therefore, teachers need to implement game-based learning in the classroom so that students have the opportunity to showcase their potential and talents [7].

Moreover, good technology design can also increase student engagement and achievement, this is because student involvement in the classroom affects students' performance. Licorish et al. [8] stated that student involvement in the classroom is important to stimulate learning and low levels of engagement are associated with poor performance. Nowadays the use of digital ICT such as augmented reality integrated with game-based learning is benefit to increase student engagement. According to [9], the augmented reality with the integration of game approach can improve not only students 'attitudes towards learning, but it also improves their learning performance. This approach can be used in a variety of subject areas in education by setting the game missions and add other learning materials according to the suitability of the subject [10].

The combination of ICT facilities and game-based learning approaches can help students in learning a skill. Thus, it can be concluded that using teaching aids that use technologies such as augmented reality and game-based learning approaches is very important in the student learning process. This is because the method is effective in helping to deliver learning content and can improve student achievement.

\section{Background of problem}

Technology development has brought many changes in education especially Malaysia. The use of technology in teaching and learning has a good impression if it is appropriately designed. The findings from the study of [11] shows that computer games do not significantly impact student learning and do not affect student attitudes towards computer science. This means that ICT implementation in the classroom cannot be seen as additional material but should be accompanied by purpose and meaning through the teacher's pedagogy [12]. 
In addition, the findings by [13] illustrate that student generally have less cognitive loads, strong motivation and a positive attitude towards the experience of reading augmented reality books. Meanwhile, the feedback from the research conducted by [14] shows that contextual collaboration with augmented reality tools is interesting, motivated and helping students get deep and long-term knowledge. The data obtained by [15] reveal that an average student perception score on teaching and augmented reality simulator is higher than 4.0; this indicates that students have a positive perception of augmented reality. These studies suggest that the use of such technologies can positively impact student learning if they are well-designed.

The focus of Standard-based Curriculum for Secondary Schools (KSSM) for lower secondary students is more than the basic knowledge mastery [16]. Geography is one of the compulsory subjects for lower secondary school students as well as other subjects. Ahmad (2016) [17] states that geography is a compulsory subject for all form one to form three students, and teachers who teach geographic subjects need to increase knowledge and skills on current issues, use the 21 st-century teaching methods and have excellent ICT skills. This is important to produce students who can use various geographical ideas and principles and make judgments on specific issues.

Wind Direction and Bearing Angels are the first topic in the form one syllabus and are one of the titles under the geographical skills that need to be mastered by students. Geographical skills enable students to review and connect in space organisations as well as focus on skills in the use of basic tools such as compass, measuring instruments, atlas and globes [16]. As this topic is the foundation of geography knowledge and skills, students must acquire it before moving on to the next topic. If this topic is taught only using a map, the students are likely to misunderstand and unable to accurately determine the direction, which will affect their mastery of other learning topics [18]. If this problem is not immediately attended, the students will continue to make the same mistakes [18].

Therefore, the Kit Pengembara that uses a game-based learning approach that integrates augmented reality technology has been developed. The details of the development of the Kit Pengembara and the integration of the game-based learning approach are discussed in the next section.

\section{The design of Kit Pengembara}

Kit Pengembara that integrates game-based learning features has been developed for students to learn Wind Direction and Bearing Angels which are the topics in the Form 1 Geography syllabus. Kit Pengembara uses a situation in the zoo as a place that requires students to play while learning by solving some of the given problems (Refer to Figure 1). 


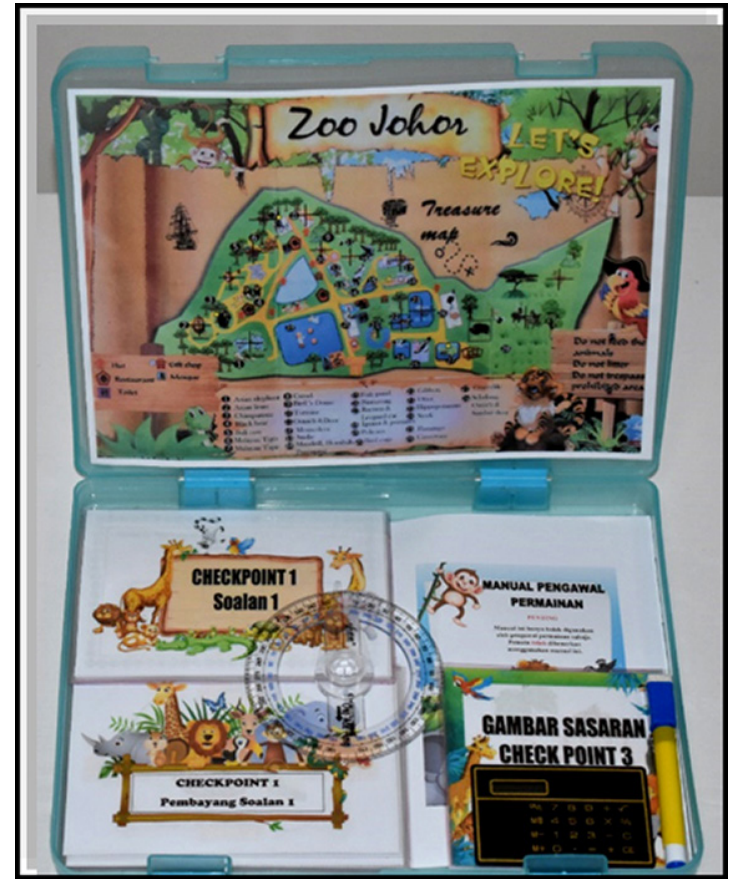

Fig. 1. Kit Pengembara

This Kit Pengembara is a game-based kit that has a quiz at every checkpoint. The number of checkpoints in this kit is seven checkpoints covering some subtopics found in Wind Direction and Bearing Angels. At each checkpoint, students need to answer quizzes as assignments. They can move on to the next checkpoint if they have completed or answered the quiz. Out of seven, only four checkpoints (Checkpoint 3, 5, 6 and 7) involve students using UniteAR to complete the quiz given. Apart from that, the game in the Kit Pengembara is controlled by a game controller, in which the game controller's role is to give instructions to players in every checkpoint game, provide hints if the players give wrong answers, and respond to answers given by the players. The description of the activity at each checkpoint is described in Table 1 below. 
Table 1. Description of the activity at each checkpoint

\begin{tabular}{|l|l|l|}
\hline \multicolumn{1}{|c|}{ Checkpoint } & \multicolumn{1}{|c|}{ Subtopic } & \multicolumn{1}{c|}{ Activity Description } \\
\hline Checkpoint 1 & Wind direction & $\begin{array}{l}\text { Students need to label the four main Wind Direction } \\
\text { in the diagram by arranging the answer choices } \\
\text { given on the question cards provided. If they answer } \\
\text { incorrectly, they are given hints to help them get the } \\
\text { correct answer. After they get the correct answer, } \\
\text { they are instructed to the next checkpoint. }\end{array}$ \\
\hline Checkpoint 2 & Wind direction & $\begin{array}{l}\text { Students complete the jigsaw puzzles provided. } \\
\text { Students who answer the questions are given hints } \\
\text { to help them get the correct answer. After they can } \\
\text { answer correctly, they are instructed to go to the next } \\
\text { checkpoint. }\end{array}$ \\
\hline $\begin{array}{l}\text { Checkpoint 3 } \\
\text { (UniteAR } \\
\text { Integration) }\end{array}$ & $\begin{array}{l}\text { How to determine the wind } \\
\text { direction using the sun }\end{array}$ & $\begin{array}{l}\text { Students watch a video related to how to determine } \\
\text { the direction of the wind using the sun and arrange } \\
\text { the steps to determine the direction of the wind } \\
\text { guided by the sun on the question card provided. If } \\
\text { they answer incorrectly, they are given hints to help } \\
\text { them get the correct answer. After they get the correct } \\
\text { answer, they are instructed to the next checkpoint. }\end{array}$ \\
\hline $\begin{array}{l}\text { Checkpoint 4 } \\
\text { (UniteAR } \\
\text { Integration) }\end{array}$ & $\begin{array}{l}\text { How to determine the wind } \\
\text { direction using the sun }\end{array}$ & $\begin{array}{l}\text { Students fill in the blanks with the correct answer } \\
\text { to the question. If they answer incorrectly, they are } \\
\text { given hints to help them get the correct answer. After } \\
\text { they get the correct answer, they are instructed to the } \\
\text { next checkpoint. }\end{array}$ \\
\hline $\begin{array}{l}\text { Checkpoint 7 } \\
\text { Integration) }\end{array}$ & Bearing angles \\
Integration)
\end{tabular}


Next, the Figure 2 below illustrates the flow of game using Kit Pengembara.

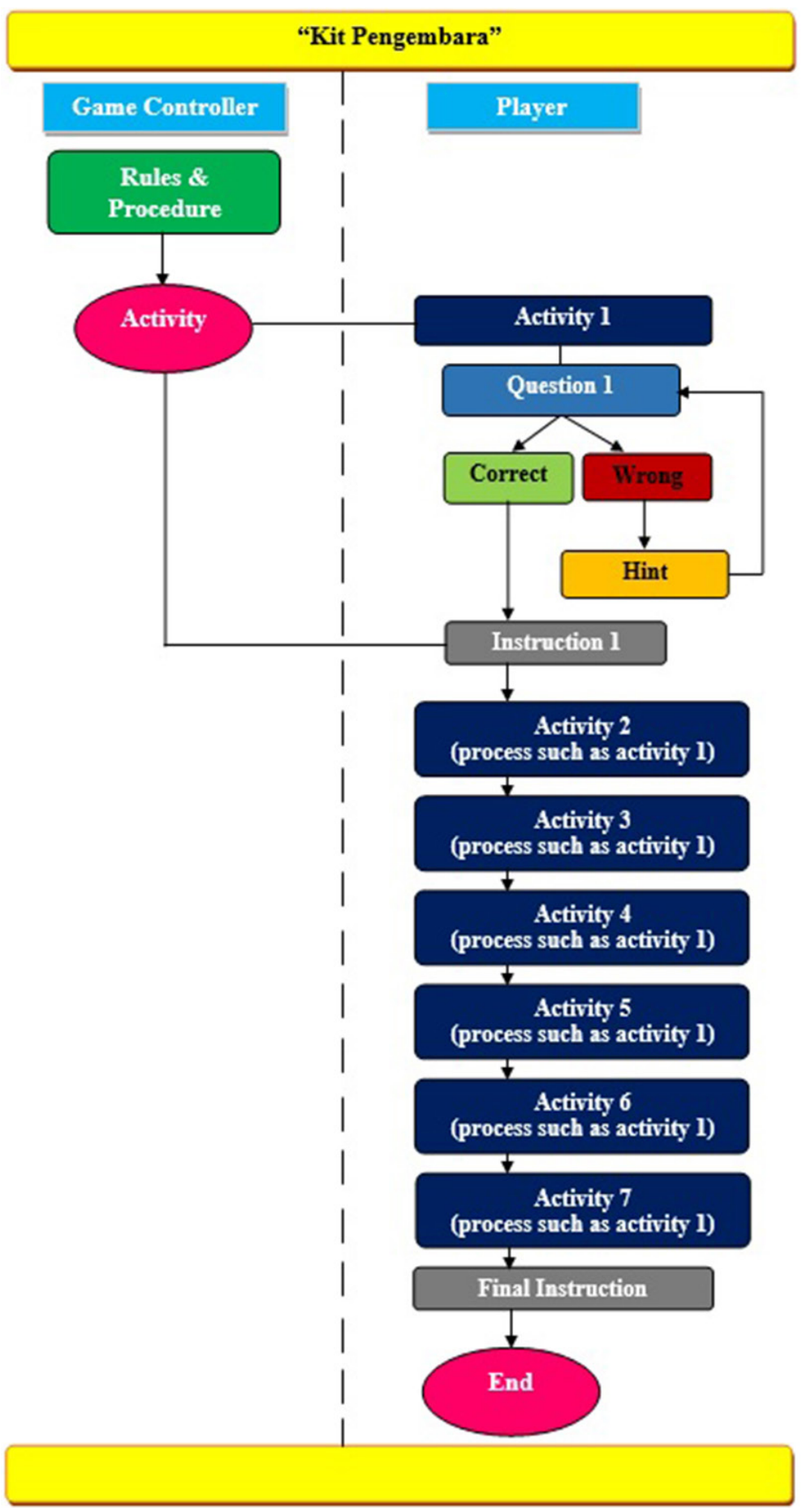

Fig. 2. Flow of game in Kit Pengembara 


\section{Game-based learning integration in the Kit Pengembara}

The Kit Pengembara integrates game-based learning features as outlined by [19]: Goals, Interaction and Feedback. These three features are the main features that are often used by other researchers in integrating game-based learning, as reported by [19] from their investigation of 31 articles from 2003 to 2014. The description of every game feature integration is found in the following sections.

\subsection{Goals}

The first feature of game-based learning is Goals. The main goal in this game is that students have to find a way out of the Zoo because they got lost in the Crocodile Park. To achieve that goal, students need to complete the tasks in the checkpoint seven, namely answering quiz questions related to the topics of Wind Direction and Bearing Angels asked in each checkpoint correctly to enable them to get instructions to exit the Zoo. Once the player achieves the goal of successfully exiting the Zoo, the game controller reads a passage stating, 'Congratulations, you have successfully exited the Zoo... The mission is over’ as shown in Figure 3.

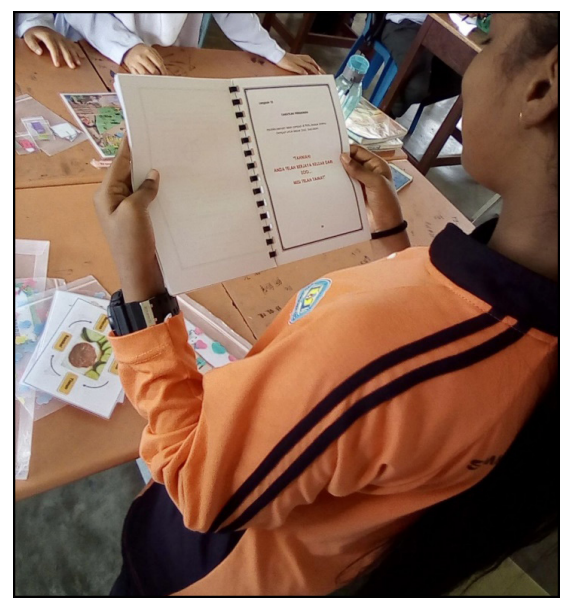

Fig. 3. The game controller reads the passage after the player achieves the goal

\subsection{Interaction}

The second feature of game-based learning is Interaction. The game is played in groups; one group has 3 to 4 members. One of the members becomes the game controller who gives instructions to the players. Players need to work with the group members in completing the tasks to get them out of the Zoo, as shown in Figure 4. 


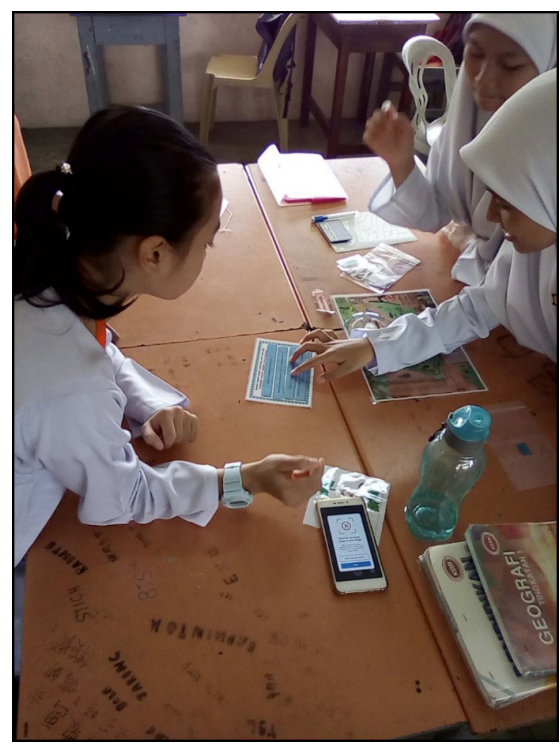

Fig. 4. Players work together in completing tasks

Besides that, players can also discuss the questions received at each checkpoint with the group members to get the correct answer. Figure 5 shows the players are having a discussion to get the correct answer for the question received.

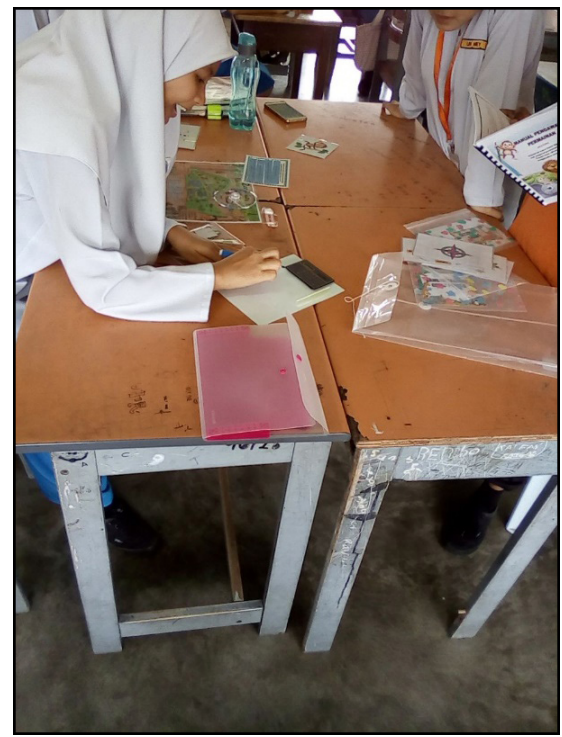

Fig. 5. Players are having a discussion in the group 
Players are also asked to use the UniteAR app to scan target pictures provided by the game controller at Checkpoints 3, 5, 6 and 7 to obtain information based on the videos or diagrams related to the topic to help them answer questions correctly at the checkpoints. Figure 6 shows a player using the UniteAR app to scan on a target image.

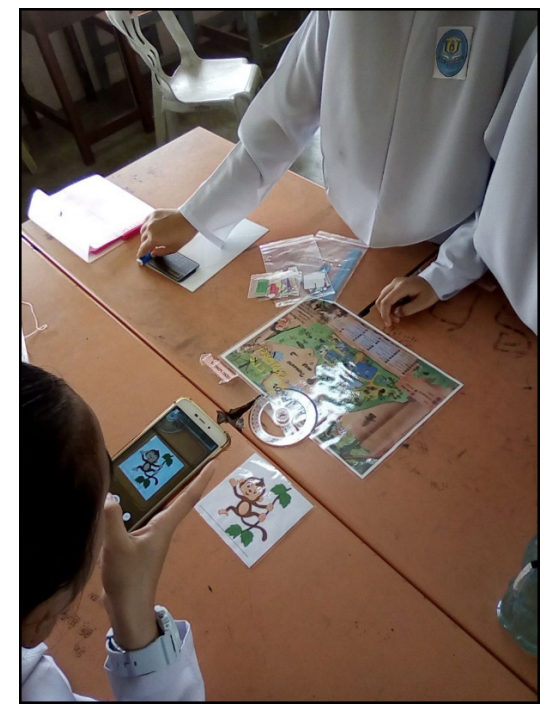

Fig. 6. Players are using the UniteAR app to scan on a target image

\subsection{Feedback}

The last feature of game-based learning is Feedback. Feedback refers to the type and information given to students who are the players after they have responded in a game. There are two types of feedback used in this study, namely outcome feedback and process feedback. The outcome feedback refers to the feedback given to the players after they get correct answer in each checkpoint, i.e., the game controller says, 'Congratulations on your correct answer'. When a player gets a wrong answer, the game controller gives a process feedback, i.e., the game controller says, 'Your answer is wrong, please try again'. After that, the players are given hints to help them get the correct answer. Figure 7 shows the game controller providing feedback to the player after the player gets the correct answer, and the figure also shows the game controller giving a hint to the player. 


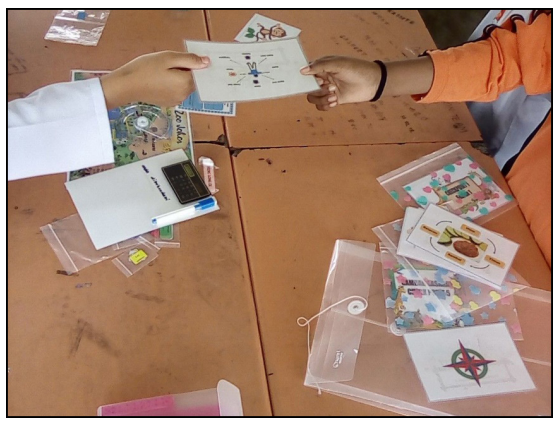

Fig. 7. The game controller gives a hint to the player

\section{Conclusion}

In conclusion, the key of game-based learning features outlined by [19] have been integrated into the games in the Kit Pengembara. The UniteAR app found in the Kit Pengembara is used at Checkpoints 3, 5, 6 and 7 to help students find the correct answer based on videos and diagrams related to the topics of Wind Direction and Bearing Angels that have been uploaded in the app. This features mobile learning help students to understand the topic well [20],[21] and further increase students' learning outcome [22]. Besides, the used augmented reality as visualization tools can also help students to understand the difficult concept [23] Therefore, it can be said that such software can increase student engagement during the learning process while making learning more meaningful and fun.

\section{Acknowledgement}

This research is supported by the Ministry of Education Malaysia and Universiti Teknologi Malaysia under the Fundamental Research Grant Scheme, Vot. R.J130000.7853.5F124 (Ref. No. FRGS/1/2019/SSI09/UTM/02/4)

\section{$7 \quad$ References}

[1] Razali, N. Z., Bahador, Z., \& Saidon, M. K. (2017). Faktor-faktor yang mempengaruhi penggunaan Vle Frog dalam kalangan guru di sekolah menengah. Proceedings of the ICECRS, 1(1). https://doi.org/10.21070/picecrs.v1i1.645

[2] Weng, N. G., Bee, O. Y., Yew, L. H., \& Hsia, T. E. (2016). An augmented reality system for biology science education in Malaysia. International Journal of Innovative Computing, $6(2)$

[3] Cai, S., Chiang, F.-K., Sun, Y., Lin, C., \& Lee, J. J. (2017). Applications of augmented reality-based natural interactive learning in magnetic field instruction. Interactive Learning Environments, 25(6), 778-791. https://doi.org/10.1080/10494820.2016.1181094 
[4] Phon, D. N. E., Ali, M. B., \& Halim, N. D. A. (2015). Learning with augmented reality: Effects toward student with different spatial abilities. Advanced Science Letters, 21(7), 2200-2204. https://doi.org/10.1166/asl.2015.6307

[5] Ke, F., Xie, K., \& Xie, Y. (2016). Game-based learning engagement: A theory-and datadriven exploration. British Journal of Educational Technology, 47(6), 1183-1201. https:// doi.org/10.1111/bjet.12314

[6] Ku, O., Hou, C.-C., \& Chen, S. Y. (2016). Incorporating customization and personalization into game-based learning: A cognitive style perspective. Computers in Human Behavior, 65 , 359-368. https://doi.org/10.1016/j.chb.2016.08.040

[7] Yusof, Y. (2019). 21 st Century Learning is Not Merely ICT. International Research Journal of Education and Sciences, 3(1), 18-23. https://doi.org/10.1155/2019/3402035

[8] Licorish, S. A., Owen, H. E., Daniel, B., \& George, J. L. (2018a). Students' perception of Kahoot!'s influence on teaching and learning. Research and Practice in Technology Enhanced Learning, 13(9), 1-20. https://doi.org/10.1186/s41039-018-0078-8

[9] Hwang, G. J., Wu, P. H., Chen, C. C., \& Tu, N. T. (2016). Effects of an augmented reality-based educational game on students' learning achievements and attitudes in real-world observations. Interactive Learning Environments, 24(8), 1895-1906. https://doi.org/10.108 $\underline{0 / 10494820.2015 .1057747}$

[10] Hung, Y. H., Chen, C. H., \& Huang, S. W. (2017). Applying augmented reality to enhance learning: a study of different teaching materials. Journal of Computer Assisted Learning, 33(3), 252-266. https://doi.org/10.1111/jcal.12173

[11] Zhao, W., \& Shute, V. J. (2019). Can playing a video game foster computational thinking skills? Computers \& Education, 141, 103633. https://doi.org/10.1016/j.compedu.2019.103633

[12] Willis, R. L., Lynch, D., Fradale, P., \& Yeigh, T. (2019). Influences on purposeful implementation of ICT into the classroom: An exploratory study of K-12 teachers. Education and Information Technologies, 24(1), 63-77. https://doi.org/10.1007/s10639-018-9760-0

[13] Cheng, K.-H. (2017). Reading an augmented reality book: An exploration of learners' cognitive load, motivation, and attitudes. Australasian Journal of Educational Technology, 33(4). https://doi.org/10.14742/ajet.2820

[14] Shirazi, A., \& Behzadan, A. H. (2015). Design and assessment of a mobile augmented reality-based information delivery tool for construction and civil engineering curriculum. Journal of Professional Issues in Engineering Education and Practice, 141(3), 4014012. https://doi.org/10.1061/(ASCE)EI.1943-5541.0000229

[15] Hsu, Y.-S., Lin, Y.-H., \& Yang, B. (2016). Impact of augmented reality lessons on students' STEM interest. Research and Practice in Technology Enhanced Learning, 12(1), 2. https:// doi.org/10.1186/s41039-016-0039-Z

[16] Ministry of Education Malaysia. (2016). Malaysia Education Blueprint 2013-2025 : 2016 Annual Report.

[17] Ahmad, M. Z. (2016). Pendidikan geografi di sekolah-sekolah Malaysia: perkembangan dan isu. Geografi, 4(1), 1-10.

[18] Munawir, A. (2020). Penguasaan konsep arah mata angin dengan metode treasure hunt di sekolah dasar. Didaktika: Jurnal Kependidikan, 9(2), 265-272. https://doi.org/10.21831/ didaktika.v2i1.28092

[19] Alaswad, Z., \& Nadolny, L. (2015). Designing for game-based learning: The effective integration of technology to support learning. Journal of Educational Technology Systems, 43(4), 389-402. https://doi.org/10.1177/0047239515588164

[20] Saidin, N. F., Halim, N. D. A., \& Yahaya, N. (2019). Framework for developing a mobile augmented reality for learning chemical bonds. International Journal of Interactive Mobile Technologies, 13(7). https://doi.org/10.3991/ijim.v13i07.10750 
[21] Hamzah, N., Abd Halim, N., Hassan, M., \& Ariffin, A. (2019). Android application for children to learn basic solat. International Journal of Interactive Mobile Technologies, 13(7). https://doi.org/10.3991/ijim.v13i07.10758

[22] El-Sofany, H., \& El-Haggar, N. (2020). The effectiveness of using mobile learning techniques to improve learning outcomes in higher education. International Journal of Interactive Mobile Technologies, 14(8). https://doi.org/10.3991/ijim.v14i08.13125

[23] Barkhaya, N. M. M., \& Abd Halim, N. D. (2016,). A review of application of 3D hologram in education: A meta-analysis. In 2016 IEEE 8th International Conference on Engineering Education (ICEED) (pp. 257-260). IEEE. https://doi.org/10.1109/ICEED.2016.7856083

\section{Authors}

Ong Ace Hong a/p Ong Long is a teacher at Dato' Usman Awang Secondary School, Johor Bahru. She received the degree of Bachelor of Education (Home Science)in year 2011 and the Master of Education (Educational Technology) from Universiti Teknologi Malaysia (UTM) in 2021. She is the secondary Geography teacher since 2012 and held the position of School Discipline Secretary since 2013. She received an Excellent Service Award from the Ministry of Education Malaysia in 2015.

Noor Dayana Abd Halim was born in Kuala Lumpur Malaysia in 1986. She received Bachelor of Science and Technology in Education majoring in Chemistry in 2009 from Universiti Teknologi Malaysia. Then, she received PhD in 2012 from the same university, UTM for Educational Technology. She has been working as Senior Lecturer at UTM since 2012. Her research interest includes online learning, augmented and virtual reality, multimedia learning, personalized learning and any related to technology in education. Currently she was a member of Young Scientists Network Academy of Sciences Malaysia (YSN-ASM). In addition, she has written numerous papers and presented at national and international conferences and seminar in the area of technology in teaching and learning. Email: noordayana@utm.my

Nurul Nadwa Zulkifli was born in Sarawak, Malaysia, in 1989. She received the bachelor degree in Science and Computer with Education, majoring in Mathematics from Universiti Teknologi Malaysia, in 2014 and the Master of Education and Ph.D in Educational Technology also from Universiti Teknologi Malaysia, in 2014 and 2019, respectively. Currently, she is working as a research officer under Uni-Technologies Sdn. Bhd. Her research interests include online learning, mobile learning, social media for learning, blended learning, peeragogy, collaborative and cooperative learning. Her recent publications include The Impact of Online Reciprocal Peer Tutoring on Students' Academic Performance (2019) and Designing Online Reciprocal Peer Tutoring Approach in Facebook (2018). Email: nurulnadwa@upm.edu.my

Nurul Farhana Jumaat is a senior lecturer from Universiti Teknologi Malaysia. She is also the editorial board for Malaysian Journal of Sociap Sciences and Innovative Teaching and Learning Journal. She is a frequent reviewer for ISI indexed journal namely Journal of Educational Computing Research (JECR) and Education and Information Technologies Journal. To date, she has secured 7 research grants in which she acted as Project Leader and a member of 44 other research related to online learning, learning analytics and computer-based T\&L. Email: nfarhana@utm.my 
Norasykin Mohd Zaid is a senior lecturer at School of Education, Faculty of Social Sciences and Humanities, Universiti Teknologi Malaysia. She received the degree of Bachelor of Science (Honors) in Computer Science (2000) and the Master degree (Educational Technology) (2006) from Universiti Teknologi Malaysia (UTM), Malaysia and the Ph.D. degree from University of Wollongong (UoW), Australia in 2013. She is the Program Coordinator of the Educational Technology Program for Postgraduate Studies since 2018. Her research interests include online education and training, information system and new media in teaching and learning. Email: norasykin@utm.my

Mahani Mokhtar is a senior lecturer and holds a post as Director, Department of Educational Foundation and Social Sciences at School of Education, Faculty of Social Sciences and Humanities, UTM. As a B. Ed TESL graduate, she had the experiences of working as an English teacher for 13 years. She has Masters in Education (Education and Development) from Universiti Teknologi Malaysia and a Doctoral Degree in Education from University of Bristol, United Kingdom. Her areas of expertise include qualitative research in education and social sciences, sociology of education, education and development and service learning. Email: p-mahani@utm.my

Article submitted 2021-09-06. Resubmitted 2021-10-23. Final acceptance 2021-10-24. Final version published as submitted by the authors. 